Универзитет у Новом Саду, Филозофски фракултет Одсек за историју, Нови Сад

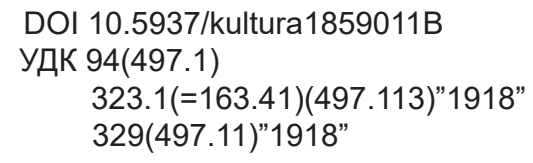

оригиналан научни рад

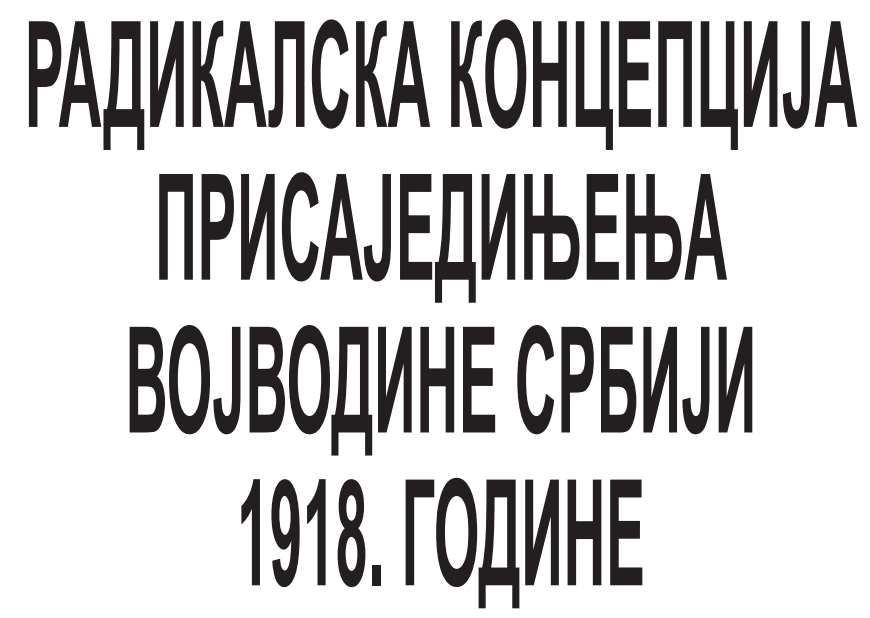

Сажетак: Иако је војвођанска Радикална странка, попут свих осталих српских организаиија у Аустроугарској, обуставила свој рад са избијањем Првог светског рата, они су из политичке пасивности изашли бурне јесени 1918. године. Сремски радикали, на челу са агилним Жарком Миладиновићем, укључили су се у рад Народног вијећа у Загребу и у том телу штитили српске интересе. На простору Баната, Бачке и Барање прваии Радикалне странке наступали су у почетку веома опрезно, страхујући од неизвесне будућности. Но, на Великој народној скупштини 25. новембра 1918. године радикалска већина је пресудила да буде донета одлука о непосредном присаједињењу Краљевини Србији, ито је било и у складу са интересима званичног Београда. Један дан раније, сремски радикали су били главна снага на Румском збору који је донео одлуку о „условном” прикљученьу Срема Србији.

Кључне речи: Војводина, Први светски рат, Присаједињење, Србија

Време турске владавине Панонском низијом обележено је покушајима локалних Срба да помогну напоре Хабзбуршке монархије да заустави продор Турака у средњу Европу - један од њих је био велики устанак у Банату 1594. године, познат по томе што је као последицу имао спаљивање моштију 
Светога Саве. Међутим, тек је Велики бечки рат довео до преокрета у турско-аустријским сукобима, а значајна улога Срба у том сукобу пружила им је могућност да изнесу своје национално-политичке захтеве. Наиме, услед аустријских пораза, дошло је до Велике сеобе Срба 1690. године, под вођством патријарха Арсенија Чарнојевића. Десетинама хиљада Срба који су се населили од Дунава и Саве па све до Тисе и Мориша, цар Леополд Први подарио је више привилегија, које су се ослањале на оне које су пречанским Србима издавали разни угарски владари у минулим столећима. У национално-политичком смислу, најважнија од Леополдових привилегија односила се на право Срба да бирају свог световног поглавара - односно војводу.

Наредни, осамнаести век, препун нових сеоба као и ратова у којима су српски граничари много задужили Хабзбуршку царевину, донео је низ нових потврда српских права у виду привилегија. Иако су привилегије Србима пружиле заштиту од покушаја мађарских великаша да их потчине, односно католичког прозелитизма и унијаћења, непрестани захтеви за засебном територијом, изношени на српским црквено-народним саборима, нису услишени. Најконкретнији од њих био је поднет на Темишварском сабору 1790. године, када је тражено формирање српског Војводства или Војводине на простору Баната, који је тек одскора био слободан од Турака. Ипак, ако не у политичко-територијалном, а оно у црквено-школском погледу Срби су од 1790. године уживали известан облик аутономије, кроз постојање Карловачке митрополије и црквено-народних сабора. ${ }^{1}$

Након више од пола века Србима се поново указала прилика да изнесу свој захтев за територијалном аутономијом, у контексту буржоаских револуција које су Европу захватиле 1848. године. Хабзбуршка монархија је такође била обухваћена револуционарним покретом, који је на њеном вишенационалном простору имао и етничка обележја. Марта 1848. године Лајош Кошут је у Пешти изнео мађарски национални програм, који је првенствено претпостављао државну самосталност. Као и све друге нације, и Срби су затражили своја права и равноправност, што је наишло на одбијање мађарске револуционарне владе. Потом је уследила радикализација српских захтева, међу којима се нашла и стара тежња за сопственом политичком јединицом. На Мајској скупштини у Сремским Карловцима, проглашена је Српска Војводовина (или Војводина), у чији су састав улазили Банат, Бачка,

1 Његован, Д. (2004) Присаједињење Војводине Србији, Нови Сад: Музеј Војводине, стр. 100. 
Барања и Срем. За њеног војводу постављен је граничарски заповедник Стеван Шупљикац, а своју Војводину Срби су морали да наредних годину дана оружјем бране од Мађара.

Аустријски цар Фрања Јосиф, коме је српска помоћ била драгоцена у обрачуну са мађарским побуњеницима, у децембру је потврдио одлуке Мајске скупштине о избору Шупљикца за војводу и Јосифа Рајачића за патријарха, али не и границе Војводине нити њене надлежности. Устав који је цар прогласио марта 1849. године наговестио је, али није успоставио српску аутономију у Хабзбуршкој монархији. Тада су се појављивале различите идеје, међу којима је била и она да се Војводина уједини са Хрватском. Коначно, царским патентом донетим новембра 1849. године створено је Војводство Србија и Тамишки Банат, са седиштем у Темишвару, које је обухватало Бачку, Срем и Банат, али без Војне границе. Та област више није била ни у каквој вези са Угарском, а на њеном челу се налазио цар, који је трајно носио титулу војводе, док је практично Војводством управљао наименовани подвојвода. Ипак, Срби нису били задовољни наградом коју су за показану оданост цару добили, јер нису биле обухваћене све територије које су они насељавали, а управни апарат Војводства су чинили углавном Немци. Коначно, у оквиру политике компромиса према мађарском националном покрету, бечки двор је и такву Војводину 1860 . године укинуо и припојио Угарској.

Недуго након укидања, Срби су отпочели борбу за обнављање Војводине. Са том намером већ 1861. године сазван је Благовештенски сабор, на коме је изнет захтев за стварање аутономије која би обухватала Срем, Банат, Бачку, Барању и Војну границу, са широким овлашћењима. Међутим, цар то није прихватио него је 1867. године постигао нагодбу са Мађарима, што је довело до стварања конфедералне Аустроугарске. Потпуно подређивање Мађарима тешко је погодило Србе у Угарској и наредних пола века их је изложило политици асимилације. Борба за национална права, коју су биле приморане да воде и друге мањине у Угарској, идеју Војводине је гурнула у други план.

Политички живот Срба у јужној Угарској у то време обележило је политичко организовање грађанске класе, задојене идејама европског либерализма и решене да се бори за српска национална права. Светозар Милетић је јануара 1869. године у Бечкереку, са групом својих истомишљеника, основао Српску народну слободоумну странку. Она је убрзо задобила велику популарност и потиснула доминацију црквене јерархије у политичком и културном животу аустроугарских Срба. Но, већ наредне деценије дошло је до подела у 
странци између старије и млађе генерације, а разлог је био став према социјалним питањима. ${ }^{2}$ Младе незадовољнике предводила је група тзв. Вршачких социјалиста, на челу са Јашом Томићем и Лазом Нанчићем. До отвореног сукоба између две фракције дошло је на новосадском збору 1881. године, на коме је Јаша Томић затражио да се у страначки програм унесе и „питање хлеба”, што није усвојено. Томићева струја је 1883. у Вршцу покренула лист Српство, а наредне године Јаша Томић је постао уредник угледне новосадске Заставе, што је њему и његовим следбеницима много значило у наступајућем периоду сукоба са „нотабилитетима” и „старом омладином” коју је предводио Михаило Полит Десанчић. Јединство у Милетићевој странци формално је постојало до 1887. године, када су настале посебне странке либерала и радикала.

Томићеви следбеници су 1887 . године основали Целокупну српску народну слободоумну странку, која је од 1891. године носила назив Српска народна радикална странка. Тиме је од једне групе истомишљеника створена политичка странка која ће постојати све до краја Првог светског рата. Све то време неприкосновени вођа војвођанских радикала био је Јаша Томић, иако је имао само функцију уредника Заставе. У првим годинама свог постојања, Радикална странка није имала чврсту организацију, него је масом чланова и присталица руководило Заставино уредништво. Тек 1893. године донет је страначки Статут, који је прописао формирање месних и среских организација, које су досезале све до Пеште, Темишвара и Арада. У време оснивања, радикалско чланство су сачињавали претежно сељаци, сиромашнији грађани и ниже свештенство, што је наилазило на подсмех либерала, који су важили за господску странку. Временом, како су заузимали полуге власти, радикалима су почели да приступају и припадници имућнијих слојева, а странком је руководило интелектуално језгро које су чинили Јаша Томић, Ђорђе Красојевић, Емил Гаврила, Жарко Миладиновић, Ђура Цвејић, Мита Клицин... По програмским одредбама, у чланство Српске народне радикалне странке могли су ступити само грађани српске националности. ${ }^{3}$

У почетку су радикали, представљајући се као верни следбеници Милетићевих идеја, као сопствени усвојили Бечкеречки програм из 1869. године, унеколико проширен на пољу социјално-економских односа. Свој Политички програм

2 Лебл, А. (1979) Грађанске партије у Војводини 1887-1918, Нови Сад: Филозофски факултет, стр. 68-69.

3 Ракић, Л. (1975) Радикална странка у Војводини до почетка ХХ века, Нови Сад: Филозофски факултет, стр. 90-91. 
Српске народне радикалне странке донели су тек 1903. године за Хрватску и Славонију, односно наредне године за Угарску. Његова основна начела била су захтев за потпуном равноправношћу Срба са Хрватима у Хрватској и Славонији и тежња за успостављањем српске аутономије у Угарској. Радикали су се залагали и за темељно поправљање друштвеног положаја сиромашних слојева, али не револуционарним него реформским путем. У погледу цркве, радикали су сматрали да велики утицај који је црквена јерархија имала на живот Срба у Аустроугарској доноси негативне последице. Због тога су константно били у жестоком сукобу са патријарсима Германом Анђелићем и Георгијем Бранковићем. Оптуживали су их за разне махинације, а ови су радикале називали безбожницима и комунистима. Радикалској критици су биле изложене како просвета (која је била под контролом цркве), тако и водеће националне установе културе (Матица српска и Друштво за српско народно позориште), којима су управљали либерали.

Став војвођанских радикала према националном питању огледао се у писању Јаше Томића, а он је нацију дефинисао као скуп појединаца прожетих свешћу о духовној сродности и припадности. Упркос лошем односу са клером, Томић је наглашавао значај православља као конститутивног елемента српске националне свести. У увођењу појма политичке нације, коју су по Закону о народностима из 1868. године сачињавали сви грађани Угарске, радикали су препознали опасност од мађаризације, те су постали носиоци борбе против владиних мера у том правцу (увођење грађанског брака, државних матрикула итд.). Априла 1894. године у Сремским Карловцима је против политике мађаризације организован велики збор свих српских странака, а на Конгресу народности у Будимпешти августа 1895. године створен је Савез народности Румуна, Словака и Срба. Тада су се војвођански радикали заложили за формирање аутономија на националном принципу и то на нивоу општина, срезова и жупанија. Према Хрватима су радикали, за разлику од осталих српских странака, задржавали велику дистанцу. Јаша Томић је у својим написима наглашавао да Срби и Хрвати јесу сродни, али да никако нису један народ. После антисрпских изгреда у Загребу септембра 1902. године, радикали су на протестном збору у Новом Саду запретили отцепљењем српских крајева од Хрватске.

На првим изборима на којима су учествовали војвођански радикали нису били успешни. На изборима за угарски сабор 1887. године кандидовали су Јашу Томића у Шајкашкој, који није изабран, а својом кандидатуром је изазвао расипање 
српских гласова и тиме онемогућио избор Мише Димитријевића, до тада јединог српског посланика у пештанском парламенту. И на изборима 1892. године радикали су остали без мандата, а наредне изборе (1896. и 1901. године) су бојкотовали, као и друге странке националних мањина. У периоду који је уследио радикали су блиско сарађивали са мађарском Независном странком Шандора Векерлеа, налазећи заједнички интерес у борби против Беча. Једна група војвођанских радикала, предвођених Миладином Величковићем - Свињеревим и Митом Клициним, издвојила се 1910. године у Српску народну странку. Они су пружали подршку Тисиној влади, због чега су од стране Томићевих следбеника погрдно били прозвани „подрепашима”. То је био други раскол међу војвођанским радикалима, после оног из 1893. године када је Крунослав Јовић са групом присталица основао Независну српску народну радикалну странку. Програмске концепције две странке су биле истоветне, али је Јовић био Обреновићевац, док су Томићеви радикали све време тесно сарађивали са Пашићевом Народном радикалном странком.

Радикална странка до 1896. године није деловала на подручју Хрватске и Славоније, већ је подржавала рад Српске самосталне странке, коју је сматрала сестринском. Међутим, те године је дошло до размимоилажења и радикали су почели да формирају своје одборе на том простору (пре свега у Срему), док су се самосталци окренули сарадњи са војвођанским либералима. И у Хрватској су радикали водили опортунистичку политику, подржавајући режим бана Рауха и замерајући самосталцима да су сувише попустљиви према Хрватима. Када је 1905. године дошло до стварања Хрватско-српске коалиције, њој су поред самосталаца приступили и радикали. Но, они су је 1907. године напустили, под изговором да се Хрвати нису одрекли хегемонистичких амбициja. ${ }^{4}$ На изборима за хрватски сабор 1908. године самосталци су у Срему добили шест, а радикали само два мандата.

Главно поприште политичке борбе војвођанских радикала био је Српски црквено-народни сабор. Као представничко тело црквено-народне аутономије Срба у Карловачкој митрополији, сабор је ономе ко би га контролисао омогућавао управљање над установама аутономије и њеним добрима. У прво време радикали су представљали мањину у сабору и били су усмерени на борбу против клерикалаца. На сабору 1897. године уједињена опозиција, коју су чинили самосталци, либерали и радикали, добила је већину и то искористила

4 Крестић, В. (1995) Историја Срба у Хрватској и Славонији 1848-1918, Београд: БИГЗ, стр. 486-487. 
да покрене питање послова које је црквена јерархија водила. Ипак, даља сарадња радикала и либерала није била могућа због убиства Мише Димитријевића које је на Туциндан 1890. године извршио Јаша Томић. На изборима 1902. године радикали су освојили убедљиву већину у сабору, за његовог председника изабран је Жарко Миладиновић, а за потпредседника Ђорђе Красојевић. Радикали су задржали власт у аутономији и после избора 1906. године, а од свих одлука које су они у своја два мандата донели, најважнија је тзв. Манастирска уредба из 1902. године, којом су манастирски поседи стављени под саборску контролу. Ипак, ти поседи нису подељени у закуп сиротињи, како су радикали обећавали у предизборној кампањи, већ њима блиским земљопоседницима. Прилично компромитовани овом афером, радикали су лоше прошли на изборима 1910. године, а угарска влада је две године касније укинула српску црквеношколску аутономију.

Наступајући Први светски рат је пресекао развој догађаја који је претио њиховом националном опстанку, али је уједно донео велика страдања Србима у Угарској. Непосредно након атентата на Франца Фердинанда у Сарајеву, 28. јуна 1914. године, почели су прогони Срба у целој Аустроугарској. Иако су осудили тај чин, попут свих осталих српских организација, војвођански радикали су били на удару режима због веза са владајућим круговима у Србији, као и са Народном одбраном, Соколима и другим патриотским организацијама. Већ дан након атентата ухапшен је Емил Гаврила, под оптужбом да је био упознат са припремама Сарајевског атентата путем својих веза са истакнутим Србима из Босне. Непосредно након објаве рата све српске установе, странке и листови су распуштени, па тако и Српска народна радикална странка, иако су њене вође давале изјаве лојалности Аустроугарској. У заједничкој изјави о распуштању српских странака: радикалне, либералне и народне, њихови прваци, укључујући и Јашу Томића, дали су следеће образложење: „У ово време, када сваки патриотски осећајући грађанин мора тежити за уједињењем са свим грађанима ради побеђења непријатеља који стоји пред нама, желимо да будемо први који, напуштањем сваког политизирања, и на тај начин уклањајући се сваком жалосном и штетном неспоразуму, желимо да раме уз раме са нашим суграђанима искрено и са свом топлином нашег искреног срца служимо угарској отаџбини.” Упркос тој изјави, Јаша Томић је 8. августа ухапшен под сумњом да је одржавао везе са Народном одбраном, а затим је интерниран, попут многих других српских интелектуалаца. Из редова војвођанске Радикалне странке интернирци су били још и Ђорђе Красојевић, Мита 
Клицин, Жарко Миладиновић, Милан Недељковић, Коста Хаџи, Емил Гаврила, Светислав Баница и др. Већина њих се из интернације вратила до почетка 1918. године, када је и Радикална странка изашла из политичке пасивности.

Први јавни иступ војвођанских радикала након 1914. године била је реакција на Мајску декларацију коју је маја 1917. године донео Југословенски посланички клуб у Бечу (њоме је затражено стварање југословенске јединице у оквиру Хабсбуршке монархије). Тим поводом, Ђорђе Красојевић је фебруара 1918. године дао свој коментар: „Радикална странка не сматра поменуту декларацију, као алфа и омега целог питања, а то тим мање, што многе појединости нису довољно прецизиране" - чиме су се радикали оградили од тријалистичких идеја састављача Мајске декларације. У пролеће 1918. године Јаша Томић је покушао да поново покрене Заставу али му то мађарска влада није одобрила. ${ }^{5} \mathrm{OH}$ је пред сам крај рата, у страху од страдања народа, одбијао да послуша савете Вељка Петровића, упућене из емиграциje, да подигне устанак у Војводини како би тиме захтеви за отцепљење од Угарске добили легитимитет пред Антантом.

Слом Аустроугарске дошао је очекивано али ипак муњевито у јесен 1918. године. Он је био последица војних успеха савезника на западном фронту, али пре свега пробоја Солунског фронта и капитулација Бугарске и Турске које су уследиле. Надирање српске и осталих Антантиних војски на север подстакли су активизам југословенских политичара у Аустроугарској. Они стварају различите локалне и регионалне националне организације, а као врхунац тог процеса дошло је, 5. октобра 1918. године, до стварања Народног вијећа Словенаца, Хрвата и Срба. Оно се залагало за уједињење у једну независну југословенску државу свих Срба, Хрвата и Словенаца из Хрватске и Славоније са Ријеком, Далмације, Босне и Херцеговине, Истре, Трста, Крањске, Горичке, Штајерске, Корушке, Бачке, Баната, Барање, Међумурја итд. У председништву Народног вијећа седели су по један Словенац, Хрват и Србин: Антон Корошец, Анте Павелић (не треба га мешати са будућим поглавником) и Светозар Прибићевић. Они су се јавно изјаснили против Аустроугарске, а за југословенско уједињење и за посебну делегацију која би их представљала на будућој мировној конференцији.

5 Милутиновић, К. Војводина и стварање Југославије, у: Присаједињење Војводине Краљевини Србији (1993), Нови Сад: Музеј Војводине, стр. 84 . 
У то време дезинтегративни процеси у Аустроугарској су доживели врхунац. Осим националних, исказивале су се и социјалне разлике. Војници су масовно дезертирали у „зелени кадар”, што је претило да доведе до револуције. Државна власт практично није ни постојала, а цар Карло је апеловао за престанак сукоба на свим фронтовима. Огласио се и Хрватски сабор, који је 29. октобра прогласио укидање Хрватско-угарске нагодбе, те је прогласио Далмацију, Хрватску и Славонију за независну државу, која је приступила Држави Словенаца, Хрвата и Срба. Међутим, та самопроглашена држава није успевала да заштити нити своје границе, нити да успостави ред и мир унутар њих. Народно вијеће, које је покушавало да управља овом „државом”, установило је покрајинске владе за Словенију, Далмацију и Босну и Херцеговину. Такође, обратило се савезницима у страху од италијанских јединица које су, одмах по склапању примирја између Аустроугарске и сила Антанте (3. новембра 1918. године), почеле да напредују дубоко у земље које су насељавали јужни Словени. Основни недостатак Државе Словенаца, Хрвата и Срба огледао се у непостојању војне силе која би била способна да заустави италијанско надирање.

Како дипломатске активности нису уродиле плодом, Народно вијеће се обратило Краљевини Србији, не би ли њена војска спречила италијанску окупацију, односно Антантиним командантима Фошу и Депереу - са истим захтевом. У ту сврху је упућена и једна делегација из Загреба у Београд. Међутим, савезници нису ништа чинили да зауставе италијанско напредовање, а нису били расположени ни да признају Државу Словенаца, Хрвата и Срба. И поред одређених политичких размимоилажења, српска влада била је много спремнија да сарађује са Народним вијећем. Она је упутила своју делегацију у Загреб, на челу са потпуковником Душаном Симовићем, а са мандатом да пружи помоћ у сузбијању могућих револуционарних покрета, односно заустављању италијанске војне силе. У томе су велику улогу играли и бивши српски ратни заробљеници, приспели у Загреб, Љубљану, Нови Сад... Истовремено, по наредби генерала Депереа, српске јединице предвођене војводом Живојином Мишићем су почетком новембра прешле Саву и Дунав и почеле да напредују све до Темишвара, Арада, Суботице, Баje, Загреба, Љубљане... Појава српских јединица изненадила je, али и зауставила италијанску војску, те спречила даље ширење тенденција друштвене револуције. ${ }^{6}$

6 Вељановић, 3. (2017) Југославија - потреба или заблуда?, Нови Сад: Музеј Војводине, стр. 130-135. 
У свим овим дешавањима бурне јесени 1918. године учествовали су и војвођански радикали. Било их је и у Народном вијећу Словенаца, Хрвата и Срба - приликом оснивања тог тела Ђорђе Красојевић је, заједно са предводницима других странака, потписао изјаву у којој се тражило самоопредељење јужних Словена и њихово присуство на наступајућој мировној конференцији. Вођство војвођанских радикала је крајем септембра 1918. године одлучило да приступи Народном вијећу „на начелима јединства троименог народа и самоопредељења". Од сремских радикала, у Народном вијећу (које је бројало 27 чланова) били су Милан Недељковић, Влада Савић и Жарко Миладиновић. Миладиновић је имао и функцију члана Средишњег одбора Народног вијећа. Деловање ове тројице било је фокусирано на заштиту српских интереса - нпр. Миладиновић је инсистирао на укидању забране ћирилице, док је Недељковић доцније тврдио да су Хрвати намеравали да прогласе самосталну републику, али да су ту намеру осујетили управо сремски радикали. Бачки, барањски и банатски радикали нису били заступљени у Народном вијећу, зато што је Јаша Томић одбио позив за приступање том телу.

У исто време, у Банату, Бачкој и Барањи одвијали су се бурни политички догађаји. Међу јужним Словенима се појавила идеја осамостаљења од Угарске. На иницијативу Тихомира Остојића, „Независни Срби и Хрвати из Јужне Угарске” су 2. октобра 1918. године са Тихомиром Остојићем саставили резолуцију у којој се истиче да они „сматрају једино Мировну конференцију за меродавну у погледу решења југословенског питања, а у вези са Бачком, Банатом и Барањом као будућим саставним делом слободне, заједничке државе свију Југословена”. Ова политичка групација је 25. октобра признала право Народном вијећу да представља јужне Словене из јужне Угарске, те је у то тело делегирала Васу Стајића као Србина и једног представника Буњеваца и Шокаца. Све ове активности одигравале су се мимо војвођанских радикала, који су одржавали контакте са грофом Михаљем Карољијем. Карољи је у Будимпешти Јаши Томићу, Кости Хаџију и Јоци Лалошевићу чак нудио места у влади и аутономију за Србе, а медији су тад пренели изјаву Хаџија да „Срби нису сепаратисти”. Од оваквих контаката јавно су се оградили сремски радикали, а Јаша Томић није дао конкретан одговор на понуду и Карољи је крајем октобра формирао владу без представника српске заједнице.

7 Ћирић Богетић, Љ. (1972) Ставови и држање првака Српске народне радикалне странке у Војводини у време Првог светског рата, Историја XX века бр. 12, Београд: стр. 180. 
Ипак, још дуго је у политичком дискурсу у Војводини била присутна теза да је Јаша Томић био веома уздржан и пун дилема новембарских дана 1918. године.

Заиста, тек 27. октобра 1918. године представници бачких радикала (уз једног банатског првака) састали су се у Суботици, расправљајући о формирању посебног представничког тела за Војводину, будући да Народном вијећу у Загребу нису признавали право заступања Војвођана, као и о покретању једног листа на српском језику. Како тада ништа није одлучено, млађи радикали су, незадовољни кунктаторском тактиком својих предводника, преузели иницијативу. Последњег дана октобра је у Бечкереку формиран први Српски народни одбор, а бечкеречки радикали су 2. новембра приспели у Нови Сад и инсистирали код Јаше Томића да покрене иницијативу за стварање централног Српског народног одбора за целу Војводину - што је он сутрадан и учинио. Основу тог одбора чинили су чланови Одбора за прихват изгладнеле деце из Босне и Херцеговине, који је пуних годину дана успешно радио у Новом Саду. Потом је формирана и војна формација одбора - Српска народна стража, покренут је Српски лист, а убрзо је, уз помоћ српских заробљеника, преузета власт у Новом Саду.

Неприкосновени вођа Српског народног одбора, његов политички референт, био је Јаша Томић. У прогласу који је Одбор упутио јавности као његов главни задатак истакнуто је право самоопредељења за Србе и остале јужне Словене из Војводине. Процес формирања локалних српских и српско-буњевачких народних одбора или већа захватио је целу Војводину, а њима су углавном управљали радикали. Читав тај подухват подржавали су српски војни одреди, који су током новембра запоседали Банат, Бачку, Барању и Срем. Сврха постојања Српских народних одбора била је двојака: са једне стране спречавање социјалних немира и евентуалне револуције, а са друге стране преузимање власти од мађарских органа и припрема изјашњавања Словена о својој будућности. У ту сврху, новосадски Српски народни одбор расписао је 17. новембра изборе за Велику народну скупштину, чије су посланике бирали сви пунолетни грађани и грађанке (по први пут у историји овог простора) словенских националности.

Војвођански Срби су тада били подељени на присталице тзв. загребачке и београдске концепције уједињења. Група интелектуалаца и политичара (Тихомир Остојић, Васа Стајић...), блиска Народном вијећу у Загребу, заговарала је уједињење у заједницу са Србијом преко тог загребачког тела. Са друге стране, војвођански радикали, а пре свих Јаша Томић, 
залагао се за непосредно припајање Војводине Србији, па потом, као дела Србије, и југословенској заједници. Та варијанта уједињења гарантовала је да ће до отцепљења од Угарске заиста и доћи, а Томић је то лаконски објашњавао: „Хоћемо да обучемо прво српску кошуљу јер нам је она најближа, а после тога заогрнућемо се огртачем Југословенства". Према сведочењима савременика, Томић је заправо маштао о стварању Велике Србије у чијем би склопу, поред Војводине са Сремом, биле и Босна и Херцеговина и јужна Далмација. ${ }^{8}$ Томић је бескомпромисно инсистирао да се у процесу уједињења избегне посредовање загребачког Народног вијећа, очекујући подршку народних представника на предстојећој скупштини, а плашећи се одлука интелектуалаца окупљених у Српском народном одбору.

У исто време, влада Краљевине Србије утицала је на развој догађаја у складу са сопственим интересима. Била је јавна тајна да Јаша Томић ништа не ради без Пашићеве сагласности, коме би присаједињење Војводине Србији увелико ојачало преговарачку позицију према Народном вијећу у Загребу. Пашићев министар Момчило Нинчић је 11. новембра примио већу групу панчевачких политичара, радикала и демократа, када им је дао инструкције у вези са предстојећом Великом народном скупштином. Да су сугестије из Београда понекад биле двосмислене, показује случај Петра Коњовића, делегата загребачког Народног вијећа. По њему је Нинчић послао поруку новосадском Српском народном одбору да на Великој народној скупштини затражи условно прикључење Србији, као и да изабере једну делегацију за Загреб, а другу за Београд. Са друге стране, Васи Стајићу, Јаши Томићу и Игњату Павласу је министар Љуба Јовановић пренео жељу српске владе да се Војводина директно припоји Србији. За директно присаједињење Србији најзаинтересованији су били радикали из Баната, који су били директно угрожени румунским претензијама. Једна делегација из Бечкерека је уочи Велике народне скупштине од Пашића тражила да се Банат самостално прикључи Србији, али то није реализовано.

Уочи Велике народне скупштине у Новом Саду је одржан припремни састанак на којем је дошло до отвореног раскола између заступника „београдске” и „загребачке” концепције уједињења. Окуражен поруком приспелом од Светозара Прибићевића: „Кидајте са Загребом!”, Јаша Томић се јавно изјаснио за директно прикључење Србији, позивајући се и

8 Петровић, М. (1951) Београд или Загреб?, Летопис Матище српске бр. 3, Нови Сад: Матица српска, стр. 202. 
на упутства српске владе. Заговорник супарничке концепције, Петар Коњовић, пренео је Нинчићев став да се Војводина присаједини Србији једино ако Народно вијеће буде одустало од уједињења. Настали неспоразум соломонски је разрешио Игњат Павлас, тврдњом да су међусобно супротстављене инструкције из Београда упућене заправо „да би оставио одрешене руке Великој народној скупштини у Новом Саду, да у овом отвореном питању заузме своје становиште". После бурне дебате сви присутни Срби, Буњевци и Словаци, укључујући и већину радикала (изузев Јаше Томића и Мите Клицина) прихватили су Коњовићеву концепцију и у том смислу сачињен је текст резолуције Велике народне скупштине. Међутим, на сам дан одржавања скупштине, Јаша Томић је променио текст резолуције који је сада одговарао његовој концепцији. Томићев поступак је омогућила чињеница да су посланици Велике народне скупштине углавном били његови истомишљеници. Већину за своју концепцију радикали су обезбедили и путем тзв. императивних мандата - на пуномоћјима изабраних посланика било је наведено да они морају гласати за директно прикључење Србији. Императивни мандати били су карактеристични пре свега за Банат.

Велика народна скупштина Срба, Буњеваца и осталих Словена у Бачкој, Банату и Барањи се 25. новембра 1918. године састала у Новом Саду. Међу 757 посланика било је 578 Срба, 84 Буњевца, 62 Словака, 21 Русин, 2 Хрвата, 6 Немаца и 1 Мађар, укључујући и седам жена, предвођених Јашином супругом Милицом Томић. Војвођански радикали су имали већину, а и наступали су добро организовано и бучно - у намери да обесхрабре присталице ,загребачке” варијанте уједињења. Јаша Томић се посланицима обратио следећим речима: „Косовски мученици! Срећно вам ослобођење!...”, а резолуција која је једногласно прихваћена била је одраз радикалских идеја:,,1. Молимо владу братске Србије, да на Конгресу мира заступа наше интересе. 2. Прикључујемо се Краљевини Србији, која својим досадашњим радом и развитком ујемчава слободу, равноправност, напредак у сваком правцу, не само нама, него и свим словенским па и несловенским народима, који с нама заједно живе. 3. Овај наш захтев хоће да помогне уједно и тежње свију Југословена, jep је и наша искрена жеља, да Српска влада удружена с Народним већем у Загребу учини све, да дође до стварања јединствене државе Срба, Хрвата и Словенаца под вођством краља Петра и његове династије". ${ }^{9}$ Националним мањинама

9 Записник Велике народне скупштине, Рукописно одељење Матице српске, М. 7417. 
посебно су гарантована сва права, што је затражено и за јужнословенски живаљ ван граница новостворене државе. Другом усвојеном резолуцијом Банат, Бачка и Барања прогласили су отцепљење од Угарске и основана је посебна Народна управа за Банат, Бачку и Барању. Све те одлуке предочене су следећег дана регенту и влади Србије од стране чланова из Новог Сада упућене делегације и са одобравањем су прихваћене. Запамћене су и речи задовољства Николе Пашића: „Знао сам да ће потомци Чарнојевићевих Срба потрефити како треба". О одлукама Новосадске и Подгоричке скупштине обавештени су званично и посланици Народне скупштине Краљевине Србије.

Унеколико другачија била је судбина Срема, који је био у саставу Хрватске и Славоније. Сремски радикали су питање припадности Срема постављали и на састанцима Народног вијећа, претећи да ће у случају оклевања са уједињењем затражити присаједињење Срема Србији. Пред изасланицима народних већа из стотинак сремских места, 24. новембра на збору у Руми донета је резолуција којом је проглашено „условно” уједињење са Србијом, односно затражено је од Народног вијећа да што пре приступи завршетку процеса уједињења, или ће се Срем директно припојити Србији. Тон овом вишестраначком збору давали су сремски радикали, пре свих Жарко Миладиновић и Милан Недељковић, а о одлукама су обавештене и Велика народна скупштина и загребачко Народно вијеће. Будући да је, недељу дана касније, Народно вијеће прихватило уједињење са Србијом, Срем се није одвојио од Хрватске и у нову државу је ушао као њен део, што је и остао, уз различите политичке перипетије, све до 1924. године. Све до тада сремски радикали су у својим написима јадиковали због тога што на Румском збору није донета одлука о безусловном прикључењу Срема Србији. ${ }^{10}$

Простором Баната, Бачке и Барање је, по одлуци Велике народне скупштине, управљао Велики народни савет, тело које је бројало педесет чланова. Као извршни орган Великог народног савета успостављена је Народна управа, која је имала једанаест одсека са народним повереницима на челу. За председника Великог народног савета изабран је радикал Славко Милетић, а радикали су добили само два ресора у Народној управи - за привреду (повереник Мита Клицин) и за финансије (Влада Манојловић). Радикали су преузели и функције великих жупана Торонталске и Бачко-бодрошке жупаније (Славко Жупански, односно Коста

10 Бјелица, С. (2005) Радикали у Војводини 1919-1941, Београд: Задужбина Андрејевић, стр. 38-40. 
Бугарски). Народна управа за Банат, Бачку и Барању, чији је главни задатак било преузимање управе на војвођанском простору од старе, мађарске администрације, неочекивано је наилазила на опструкцију српских власти, а први председник владе Краљевине Срба, Хрвата и Словенаца, Стојан Протић, ускоро је позвао на демисију Народне управе. Њена коначна ликвидација проглашена је 11. марта 1919. године. ${ }^{11}$

Када су у наступајућем времену Војводину снашле економске недаће, многи су њихове узроке проналазили у укидању покрајинске управе, за шта је кривица приписивана руководству војвођанских радикала и његовом несналажењу у новом времену. Према признању самог Јаше Томића, када је на састанку са представницима српске владе и изасланицима Народног вијећа из Загреба постављено питање шта Војводина тражи за себе, он је одговорио: „Ништа! Србија нас је ослободила и хвала јој!” Војвођанске радикале су њихови супарници оптуживали и да су и сами радили на распуштању Народне управе, због тога што им није одговарала њена страначка структура. У наредним годинама, војвођански радикали су увек са поносом истицали своје заслуге за успешан завршетак процеса присаједињења Војводине Србији. Међутим, стварност новостворене Краљевине Срба, Хрвата и Словенаца често је доводила до разочараности многих радикалских првака, па и самог Јаше Томића, који је наводно слутио: „Ако они овако наставе, ова наша прва генерација слабо ће имати корист од ослобођења. Ми ћемо се опет морати борити као и пре, разлика је само у том, што ћемо место у Вац ићи у Пожаре-вац“.

\section{Извори:}

Записник Велике народне скупштине, Рукописно одељење Матице српске, М. 7417.

\section{ЛИТЕРАТУРА}

Бјелица, С. (2005) Радикали у Војводини 1919-1941, Београд: Задужбина Андрејевић.

Вељановић, 3. (2017) Југославија - потреба или заблуда?, Нови Сад: Музеј Војводине.

Јудин, Љ. (1968) О раду народне управе за БББ 1918-1919, Зборник Матище српске за друштвене науке бр. 51, Нови Сад: Матица српска.

11 Јудин, љ. (1968) О раду народне управе за БББ 1918-1919, Зборник Матице српске за друштвене науке бр. 51, Нови Сад: Матица српска, стр. 51. 


\title{
СЛОБОДАН БЈЕЛИЦА
}

Крестић, В. (1995) Историја Срба у Хрватској и Славонији 18481918, Београд: БИГЗ.

Лебл, А. (1979) Грађанске партије у Војводини 1887-1918, Нови Сад: Филозофски факултет.

Милутиновић, К. Војводина и стварање Југославије, у: Присаједињење Војводине Краљевини Србији (1993), Нови Сад: Музеј Војводине.

Његован, Д. (2004) Присаједињење Војводине Србији, Нови Сад: Музеј Војводине.

Петровић, М. (1951) Београд или Загреб?, Летопис Матиие српске бр. 3, Нови Сад: Матица српска.

Ракић, Л. (1975) Радикална странка у Војводини до почетка XX века, Нови Сад: Филозофски факултет.

Ћирић Богетић, Љ. (1972) Ставови и држање првака Српске народне радикалне странке у Војводини у време Првог светског рата, Историја ХХ века бр. 12, Београд.

Slobodan Bjelica

University in Novi Sad, Faculty of Philology - History Department, Novi Sad

\section{THE RADICAL PARTY CONCEPT FOR VOJVODINA'S UNIFICATION WITH SERBIA IN 1918}

\begin{abstract}
When the World War I broke out, the Radical Party ceased operating along with all other Serbian organizations in Austria-Hungary. Its leaders spent the subsequent war years in the internment. The above mentioned Radicals reactivated during a rather tumultuous autumn in 1918. The Radicals from Srem, led by Žarko Miladinović, started their cooperation with the National Council from Zagreb. Their main activities were to protect the Serbian national interests and to demand an unconditional unification with Serbia. The Radical leaders from Bačka, Baranja and Banat headed by Jaša Tomić were very cautious in their public appearances because they were not sure of the future of the Hungarian borders. It was not until the beginning of November that the Serbian National Board was formed. A number of such bodies were formed in many places all over Vojvodina. The culmination of these activities was the Great National Assembly held in Novi Sad on November 25th. Due to the Radicals and Jaša Tomić especially, a decision to annex Bačka, Baranja and Banat to Serbia was made in this Assembly: they decided to join them directly to Serbia and not through the National Council in Zagreb, which was the other alternative. A day before the above mentioned event, representatives of the National Council from Srem also expressed their support to a direct unification with Serbia at their meeting held in Ruma.
\end{abstract}

Key words: Vojvodina, World War I, unification, Serbia 